\title{
Unequal Pathways. School-to-Work Trajectories for Children of Turkish and Western-Balkan Origin in Switzerland and Austria
}

Philipp Schnell* and Rosita Fibbi*

* Swiss Forum for Migration and Population Studies, University of Neuchâtel, CH-2000 Neuchâtel, philipp.schnell@unine.ch and rosita.fibbi@unine.ch.

\section{Abstracts \\ Unequal Pathways. School-to-Work Trajectories for Children of Turkish and Western-Balkan Origin in Switzerland and Austria}

This paper investigates educational and occupational pathways of children of Turkish and Western-Balkan origin and of the majority population in Austria and Switzerland. Using a representative sample of 2186 respondents living in two Swiss and two Austrian urban areas, our results show that descendants of immigrants have less chances to follow a constant successful path from education to occupation in both countries, mainly because successful trajectories are determined by the parent's socioeconomic status. However, young adults of Turkish and Western Balkan origin in Switzerland are more often upward mobile than the majority group. Altogether, our results indicate slightly greater chances for upward mobility among young adults in Switzerland in comparison to Austria.

Keywords: Second generation, educational and occupational pathways, social mobility, Switzerland, Austria

\section{Ungleiche Laufbahnen. Bildungs- und Berufsverläufe von Nachkommen türkischer und exjugoslawischer MigrantInnen in Österreich und der Schweiz}

Der Beitrag analysiert Bildungs- und Berufsverläufe von Nachkommen türkischer und ehemals jugoslawischer MigrantInnen im Vergleich zu einheimischen jungen Erwachsenen in Österreich und der Schweiz. Unter Verwendung einer repräsentativen Erhebung mit insgesamt 2186 Befragten aus jeweils zwei Städten pro Land zeigen unsere Ergebnisse, dass Nachkommen von MigrantInnen in beiden Ländern eine geringere Chancen haben, akademisch orientierte Bildungswege einzuschlagen und beruflich höher gestellte Positionen auf dem Arbeitsmarkt einzunehmen. Diese Benachteiligung für die sogenannte zweite Generation lässt sich weitestgehend über die soziale Positionierung der Eltern (sozioökonomischer Hintergrund) erklären. Allerdings zeigen unsere Ergebnisse auch, dass Nachkommen von MigrantInnen im weiteren Verlauf ihrer schulischen und beruflichen Laufbahnen im Vergleich zu jungen Erwachsenen ohne Migrationshintergrund deutlich häufiger aufwärts mobil sind. Dabei sind die Chancen auf Aufwärtsmobilität für MigrantInnennachkommen in der Schweiz größer als in Österreich.

Schlüsselwörter: Zweite Generation, Bildungs- und Berufsverläufe, soziale Mobilität, Schweiz, Österreich

\section{Parcours inégaux. Les trajectoires de l'école à l'emploi des enfants originaires de Turquie et des Balkans occidentaux en Suisse et en Autriche}

Cet article analyse les trajectoires éducatives et professionnelles des jeunes adultes originaires de Turquie et des Balkans ainsi que celles des groupes majoritaires en Suisse et en Autriche, en s'appuyant sur un échantillon représentatif de 2186 répondants habitant deux contextes urbains dans chacun de ces pays. Les résultats montrent que dans les deux pays les enfants d'origine immigrée ont moins de chances de fréquenter tout au long de leur parcours les filières scolaires et professionnelles les plus prestigieuses, puisque ces trajectoires sont pour l'essentiel déterminées par le statut socio-économique des parents. Pourtant, les jeunes originaires de Turquie et des Balkans en Suisse sont plus nombreux à montrer une mobilité ascendante que les jeunes issus du groupe majoritaire. Globalement les chances de mobilité ascendante tendent à être légèrement plus élevées en Suisse qu'en Autriche.

Mots-clés: Deuxième génération, trajectoires éducatives et occupationnelles, mobilitésociale, Suisse, Autriche 


\title{
Unequal Pathways. School-to-Work Trajectories for Children of Turkish and Western-Balkan Origin in Switzerland and Austria
}

\author{
Philipp Schnell* and Rosita Fibbi ${ }^{\star}$
}

\section{Introduction}

Within the last two decades, children of immigrants in Western Europe are leaving school and entering the labour market in increasing numbers. Their achievements and the opportunities available to them are often regarded as the "litmus test" not just for integration, but for the success or failure of policies in this field. Comparative research on educational outcomes has identified relatively clear patterns across countries: Children of immigrants, in particular descendants of labour migrants from Turkey and Western Balkans, seem to be less disadvantaged in countries whose education systems have rather late than early selection, operate with general rather than vocational qualifications at upper secondary level and hold a high degree of permeability between educational tracks within the system (Alba et al. 2011; Crul, Schnell, et al. 2012; Schnell 2014; van de Werfhorst et al. 2014). Among these northwestern European countries are France, Sweden and to some extent the Netherlands. Results on educational and occupational outcomes by children of immigrants are often contrasted with findings in countries such as Austria, Switzerland or Germany, whose educational systems are characterized by early selection, an extensive vocational training system at the upper secondary level and few opportunities to enter tertiary education. In these countries, the educational performance by children of immigrants seems to be lower than in comprehensive systems, as demonstrated by poor performance in achievement tests, more frequent participation in lower ability tracks and reduced chances of achieving tertiary education (Heath and Brinbaum 2014). In other words, the comparative focus is usually on the socioeconomic achievement by children of immigrants in comprehensive versus tracked systems, while differences between countries with rather similar structural features - such as the three aforementioned German speaking countries - are scarce. The few studies investigating educational and occupational outcomes in countries with similar instituitional features, such as Gaupp and colleagues' (2012) study on Switzerland and Germany, frequently lack information on the country of origin among the

Swiss Forum for Migration and Population Studies, University of Neuchâtel, CH-2000 Neuchâtel, philipp.schnell@unine.ch and rosita.fibbi@unine.ch.

1 This study was carried out in the frame of the "Pathways to Success" project funded by the Mercator Stiftung Schweiz. 
second-generation or face relatively small sample sizes compelling researchers to compound origins in aggregated minority groups.

In this article, we redress this research gap by turning to the topic of socioeconomic success and failure of the second generation of Turkish and Western-Balkan origin in Austria and Switzerland, two of the largest immigrant populations in both countries today. We focus on these two German-speaking countries because they share a number of important generic institutional arrangements in the education system and have comparable migration regimes. Despite these general similarities, we argue that the compared countries differ in "smaller" and often neglected institutional features, such as minor difference in age at selection, the degree of permeability between tracks within the education system, the relative importance of low qualifying vocational education and training (VET) as well as labour market characteristics which might provide varying opportunities for turning points in school-to-work trajectories, contributing to different rates of upward mobility between the two countries.

We give special attention to the notion of educational and occupational trajectories and differentiate various avenues to gain socioeconomic advancement. This design, stemming from life course research, gives a portrait of educational and occupational trajectories from the beginning of school tracking until the current stage in the labour market when all education-to-work transitions are completed (Groh-Samberg et al. 2012; Laganà et al. 2014). This "trajectory perspective" provides new insights into the process-like character of socioeconomic careers of children of immigrants, as recently shown in a similar study on Switzerland (Schnell and Fibbi 2015). It highlights not only the interplay between individual level factors and institutional arrangements of host country systems but also transforms the generalised understanding of thresholds between "success" and "failure" at the end point into more detailed sequences of failures and successes. The questions guiding this article are: do second-generation immigrants of Turkish and Western-Balkan origin experience upward mobility in the two compared countries, and if so, how? Does the degree of upward mobility differ between Austria and Switzerland? What are the factors and determinants associated with the educational and occupational careers of young adults of immigrant origin in Austria and Switzerland?

\section{Austria and Switzerland in comparative perspective}

The Austrian and Swiss education systems share a number of institutional similarities (compare Table 1): late entry age into school, a developed tracking system, similar age at the end of compulsory education and a comparable public expenditure on education. However, first selection occurs earlier in Austria (10) than in Switzerland (12). Rigid selection of students into different education strata at an early age (prevailing 
Table 1 Characteristics of the education system and labour market in Austria and Switzerland

\begin{tabular}{|c|c|c|c|}
\hline & & Austria & Switzerland \\
\hline \multicolumn{4}{|c|}{ Education } \\
\hline 1 & Age at entering compulsory education & 6 & 6 \\
\hline 2 & Years spent in school until first tracking & 4 & 6 \\
\hline 3 & Age when first selected & 10 & 12 \\
\hline 4 & Number of tracks at lower secondary level & 4 & 3 \\
\hline 5 & Age when leaving compulsory education & 15 & 15 \\
\hline 6 & VET-rate as \% of upper-secondary education 2008 & 88.4 & 71.0 \\
\hline 7 & Public expenditure on education as \% of GDP (2008) & 5.5 & 5.0 \\
\hline \multicolumn{4}{|c|}{ Labour market } \\
\hline 8 & NEET rate among 15-24 years old (2007) & 7.1 & 6.2 \\
\hline 9 & Youth-adult unemployment ratio (2008) & 2.6 & 2.6 \\
\hline 10 & Share of young people (15-24) in the total active population & 0.27 & 0.27 \\
\hline & Share of manual and elementary occupations 2007 & 36.5 & 29.3 \\
\hline
\end{tabular}

Notes: Indicators have been collected for 2007/2008 (base year of the TIES survey). VET=Vocational education and training; NEET = Not in Education, Employment, or Training.

Sources: Indicators: 6-7 = Eurostat (2013a; 2013b); $8=$ OECD (2012); $9=$ Nations Unies (2008); $10=$ GomezSalvador and Leiner-Killinger (2008); $11=$ Romans and Preclin (2008).

in German speaking countries, such as Austria and Switzerland) has been found to have a strong negative association with educational mobility (Pfeffer 2008). The relative importance of vocational education and training (VET) in upper-secondary education is, however, lower in Switzerland than in Austria.

School-to-work transitions in Switzerland are characterized by highly institutionalized trajectories, in particular in upper secondary education (Bertschy et al. 2007), leading to secure and structured pathways to upper-secondary (vocational) tracks, which substantially reduces the chance of ending up in low paid, unskilled work or unemployment (Gaupp et al. 2012, 301). On the contrary, similar institutionalized trajectories are almost absent in the Austrian education system and opportunities to move upwards towards upper-secondary tracks after being selected for the vocationally orientated track at age 10 remain low (Bacher 2010; Schnell 2014). In other words, the degree of permeability, which defines the potential for moving between tracks in upper secondary education, differs between Austria and Switzerland.

Indicators describing the generic conditions framing young workers' entry and activity on the labour market are displayed at the lower part of Table 1. The rate of youth neither in education nor in employment (NEET - Not in Education, Employment or Training) appears to be higher in Austria than in Switzerland. The 
relative position of young people in the whole labour market is similar in the two countries however, both in terms of the youth-adult unemployment ratio and with respect to their share in the total active population. At the same time, the Austrian labour market offers a higher proportion of less skilled occupations than the Swiss labour market.

\section{Theoretical considerations}

In this contribution we use the framework proposed by "integration context theory" (Crul and Schneider 2010) to examine the actual school-to-work trajectories of members of the Turkish and Western-Balkan second generation in Austria and Switzerland. As Crul and Schneider (2010) argued in their "integration context theory," school and labour market outcomes must be seen as part of a system's idiosyncrasy, which is generally only revealed in comparison across countries. Differences in national contexts may help to explain the diverse outcomes for children of immigrants across Europe, given the different institutional arrangements. The most important perspective in integration context theory is therefore its focus on the generic institutional arrangements of the education system and the labour market. The second important perspective in the "comparative integration context theory" includes the agency of individuals and groups, i. e. the ways in which they actively develop options and make choices, challenge given opportunities and structural configurations (Crul and Schneider 2010, 1260). In different contexts, individuals' subjective and objective options for gaining access to and for claiming participation in education and work depend on various individual and group resources. Different school and labour market characteristics at each stage of the trajectory interact with available resources leading to different outcomes (Schnell 2014).

When explaining social and economic mobility of the children of immigrants, the main focus of research has been on family background characteristics and therefore on resources within the family of origin, finding that parents with greater socioeconomic resources are better able to obtain the relevant financial and non-monetary means to support their children's socioeconomic success (Glick and White 2003; Kao and Rutherford 2007). We expect to find strong correlations between social origin and the highest and most prestigious educational and occupational attainment due to intense differentiation and rigid selection of students into different ability tracks early in the education systems of Austria and Switzerland. The theoretical explanations offered for this strong relationship presume parents' active guidance in advising their children on educational choices (Pfeffer 2008). First, highly educated parents tend to have a good understanding of the school system and are a crucial resource when children are confronted with educational choices between tracks at an early stage (strategic knowledge). Second, more educated parents might be better equipped to 
assist their children in their learning process by providing direct help, for example with homework, or relevant financial and non-monetary resources, such as books at home (content knowledge). Turkish and Western-Balkan second generation in both countries are often from less-advantaged families (Herzog-Punzenberger 2003; Meyer 2003) and often lack the strategic and content knowledge associated with the successful completion of an educational degree. As a result, they seem to fail to enter or to continue on the more prestigous pathways. By contrast, parents with greater social and economic status who have succeeded in the educational system may have greater cultural capital - for example, better language skills or relationships with others - which might in turn influence the school performance of their children, reinforcing better social and economic outcomes for the next generation.

We further assume that greater levels of parent-child communication are associated with higher probabilities for socioeconomic success. Previous studies indicate that parental involvement has been found to be positively related to educational and occupational outcomes as it provides greater support and tighter monitoring of children's activities, in particular for descendants of immigrants (Turney and Kao 2009, 258).

Important additional resources for socioeconomic success may also be acquired outside the family home. Teachers and peers have been identified in previous studies as the most significant agents providing such resources. Institutional contact with school personnel such as teachers is important given their ability to negotiate school resources. Teachers can also provide credible work references and are therefore also a valuable asset in job placement. Youth who find jobs through school contacts such as teachers may be employed in work with more promising trajectories, leading to higher earnings and better occupational prospects (Rosenbaum et al. 1999, 191). In addition, good student-teacher relationships can help disadvantaged and children of immigrant origin feel welcome in the host country, which can in turn positively affect their educational attainment (Stanton-Salazar 2001).

Social and economic achievement processes may also be significantly impacted by peer group (Campbell 1980; Duncan et al. 2001). Close friends can offer the strategic knowledge needed to navigate the educational system or decide on jobs. They may also share content knowledge, such as help with homework, which can facilitate socioeconomic advancement. Immigrant youth rely on peer contact in school and work more than their majority peers due to less access to pro-scholastic networks and embedded resources within their own families (Gibson et al. 2004). Non-immigrant peers also provide important resources and information that can improve the work opportunities of second-generation youth (Kanas et al. 2011).

Unequal treatment may hinder upward socioeconomic mobility on an individual basis, whether at school (Kronig 2007) or on the labour market (Loury 
2002, 99). ${ }^{2}$ Perceived discrimination (Skrobanek 2014) may act similarly, leading to discouragement and lower aspirations. Institutional discrimination in school or the workplace may equally be seen as a challenge to work hard to succeed, in particular among children of immigrants (Kasinitz et al. 2008).

\section{$4 \quad$ Data and variables}

\subsection{Data}

We use data from the "The Integration of the European Second-generation" (TIES), a collection of data about the children of immigrants from Turkey, Western Balkans and Morocco in 15 European cities in eight western European countries (Crul, Schneider, and Lelie 2012). The TIES samples in Austria and Switzerland contain information for descendants of immigrants from Turkey and Western Balkans. ${ }^{3}$ Migration to Switzerland from those non-EU countries developed first as labour migration during the economic recovery after the oil crisis under a migratory regime increasingly differentiated from the one reserved for EU migration (Fibbi et al. 2015). After 1964, Austria reached nearly full employment, which triggered large-scale recruitment of foreign workers from Turkey and Yugoslavia through the signing of the bilateral recruitment agreements. The oil crisis in 1973 led to growing family reunification and a rapid increase in the number of Turkish and WesternBalkan family members in Austria in the years after 1974. Until the breakdown of the Eastern bloc in 1989, Austria mostly attracted migrants from Yugoslavia and Turkey. ${ }^{4}$ Various studies show that those migrant groups have been targeted by discrimination and stigmatisation in both countries (Juhasz and Mey 2003; Fibbi et al. 2006; Sievers et al. 2014).

Respondents of immigrant origin in the TIES survey were sampled regardless of their present citizenship(s) if they were born in the survey country and at least one of their parents was born abroad. Additionally, the survey was conducted with a majority group of Austrian/ Swiss nationality whose parents were both born in

$2 \quad$ It is necessary to analytically distinguish between institutional discrimination and perceived discrimination. The former designates unfair everyday-life practices ensuring domination of certain groups over others which are so routinized that they need no further justification (Gomolla and Radtke 2000). The latter, also called self-reported discrimination, refers to experiences of unfair treatment that the victim subjectively interprets as such. Therefore, it might be flawed by underestimation (Simon 2012). Although fully aware of the differences between the two constructs, in the analysis that follows we can only rely on data collected in the survey which unfortunately only accounts for the subjective perception of discrimination.

3 The expression "Western Balkans" designates a region comprising the successor States of former Yugoslavia and Albania (see the institutional terminology of the European Union) (e. g. the Thessaloniki Declaration, accepted at the end of the EU-Western Balkans summit, June 21, 2003).

4 Table A1 in the electronic supplementary material provides immigration related characteristics for the parental generation in Austria and Switzerland based on the TIES survey. Please see www. migration-population.ch. 
the country. At the time of the interviews (2007-2008), all respondents were between 18 and 35 years old. The TIES survey was carried out in the urban areas of Linz and Vienna in Austria, and Basel and Zurich in the German-speaking region of Switzerland, since the largest number of second-generation youth from Turkey and Western Balkans is living there. The response rate varied from $36 \%$ to $47.5 \%$ among groups and study areas in Switzerland and between $42 \%$ to $70 \%$ in Austria (Groenewold and Lessard-Phillips 2012, 48-50; Schnell 2014, 225). Given our focus on socioeconomic trajectories of young adults we excluded all respondents who were still in school at the time of the interview and had no labour market experience. This resulted in a total sample size of 1049 and 1107 respondents in Austria and Switzerland, i.e. $82 \%$ and $73 \%$ of the original sample, respectively.

\subsection{Variables}

\subsubsection{Dependent variable}

Educational and occupational trajectories. We use retrospective autobiographical statements on individual life courses collected in the TIES survey in order to explore various trajectories to gain socioeconomic advancement. ${ }^{5}$ This design gives a portrait of trajectories from compulsory schooling until the current stage in the labour market. We focus on four stages to compile socioeconomic trajectories (for a similar approach, see Hao and Pong 2008):

, Lower secondary education is divided into school types with (1) elementary requirements (basic-level performance) and (2) extended requirements (advanced-level performance).

- Upper secondary education is categorized on the basis of the International Standard Classification of Education (ISCED) into (1) vocational training oriented (ISCED 3c, 3b - for a maximum length of 2 years) and (2) Matura/ Baccalaureate oriented (ISCED 3a, 3b for 3 years and more) school types. ${ }^{6}$

, Tertiary education includes all tertiary institutions (ISCED 5a, 5b) as one category since participation beyond upper secondary education is still relatively low in both countries.

, Current occupational position is measured on the basis of the EriksonGoldthorpe-Portocarero (EGP) classification scheme (Erikson et al. 1979). Due to small sample sizes, the EGP classes were recoded as (1) unskilled workers (VIa, VIb), (2) skilled workers (V, VI), (3) routine workers (IIIa, IIIb, IVa, IVb) and (4) executives and professionals (I, II). Those who were not

5 Retrospective data has a high potential for bias given its reliance on autobiographical memory. However, interviewing young adolescents about their educational and early occupational careers, events which have recently taken place, the data may have a high potential of obtaining faithful autobiographical details.

6 The limited number of youth having attended ISCED $4 \mathrm{a}$ and $4 \mathrm{~b}$ in Switzerland is classified with the same criteria. 
participating in the labour force at the time of the interview have been coded as (5) economic inactive. ${ }^{7}$

These four dimensions in our data yielded a total of 41 and 42 combinations in Austria and Switzerland respectively, each with a unique sequence of stages characterizing an individual socioeconomic pathway. Related trajectories have been classified into a total number of four distinct families of trajectories. The families of trajectories were defined so as to build analytical meaningful groups in accordance with previous research (Hupka-Brunner et al. 2012; Laganà et al. 2014).

For clarification, consider the following example from the Swiss data: 111 respondents in our data started their lower secondary education in a school type with elementary requirements. Afterwards, they continued in a school track leading to the Swiss "Baccalaureate" diploma and are skilled workers today. Others followed the same trajectory during lower and upper secondary education but attended tertiary education before entering the Swiss labour market as professionals. We grouped both trajectories into one pathway since both describe young adults who successfully negotiated more prestigious tracks in the education system leading to professional or at least routine occupational positions. ${ }^{8}$

Our final measure of socioeconomic trajectories has the following four categories: (1) The constant successful trajectories summarizes paths in which young adults successfully negotiate through more prestigious educational tracks with extended requirements leading to professional, routine and skilled occupational positions (as described in the example above). (2) In contrast, the constant unsuccessful trajectories start with elementary requirements in lower secondary education, vocational- training-oriented upper secondary education (at maximum) and end in unskilled work or inactivity. Next, (3) the group of upward trajectories summarizes avenues that lead to upward mobility. As shown in Figure 1, upward mobility can appear in education, on the labour market or through a combination of both. The latter, for instance, classifies people who start their educational career in lower secondary education with elementary requirements, continue in academic-oriented or vocational upper secondary education and enter the labour market as professionals, routine or skilled workers. It is worth noting, however, that a very small group of people experienced upward mobility through a bumpy and discontinuous trajectory (compare Figure 1). The last group classifies trajectories as downward

$7 \quad$ We acknowledge a major limitation in our data: the TIES survey allows tracing back educational trajectories in great detail (compare dimensions 1 to 3), but it does not contain comprehensive data on all occupational career steps after leaving the education system and before the current occupational status. We therefore had to refrain from applying sequence or event history analysis. In additional analysis, however, we controlled for the number of prior jobs held before the current occupational position (available in TIES) but found this indicator to be highly correlated with age. Thus, we believe that controlling for age in all multivariate analyses does justice to potential differences occurring due to variations in the number of prior jobs. See Electronic supplementary materials for more details (www.migration-population.ch). 
Figure 1

Families of trajectories grouped as pathways

(dependent variable) - schematic presentation

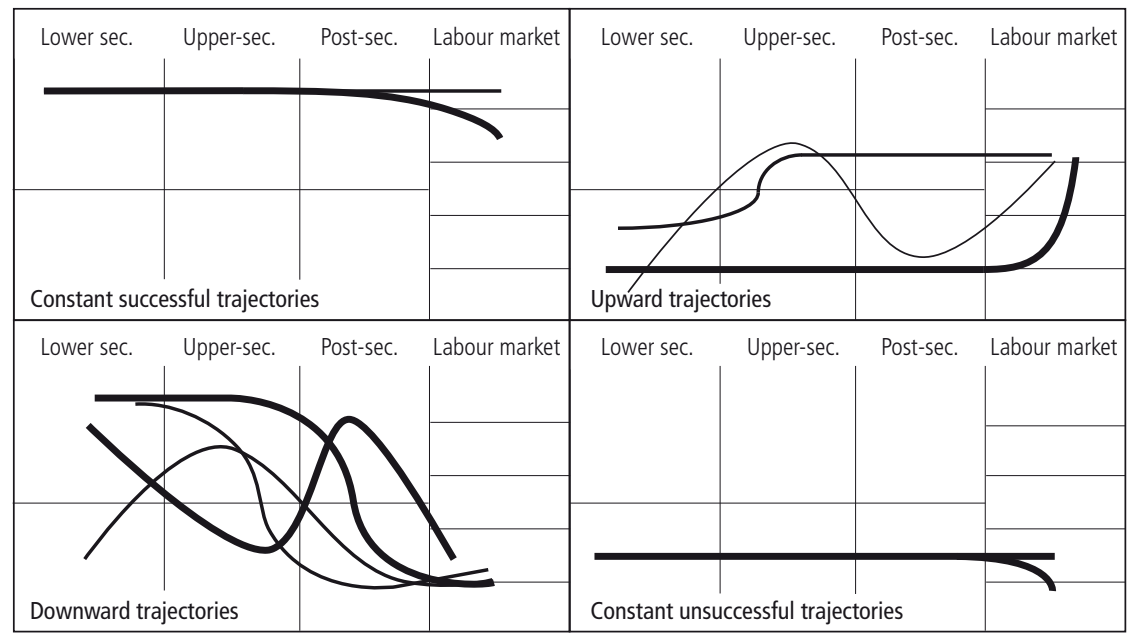

Notes: Low-sec=Lower-secondary education; Upper-sec=Upper-secondary education; Post-sec= Post-secondary/tertiary education. Bold lines represent the most numerical trajectories in our data within the respective classification of trajectories.

mobility path (4). As displayed in Figure 1, downward mobility might occur during education (starting high but then losing ground), on the labour market or through discontinuous trajectories.

\subsubsection{Independent variables}

Parental socioeconomic status. We followed previous studies (e. g. Glick and White 2003; Portes and Rumbaut 2001) and created a composite measure to capture the parental socioeconomic status (SES) of our respondents by including the following information: Mother's and father's education and occupation, the number of books in the family home and a dummy variable indicating whether a quiet place to study for the child was available at home. We applied polychoric principal component analysis to derive our standardized composite measure for parental SES from the four variables (Kolenikov and Angeles 2009). This final standardized scale ranges from 0.7 to 3.5 and is treated as a continuous variable in the statistical analysis. An increasing factor score indicates an increase in the level of parental SES.

(Above-average) Family size is calculated on the basis of the total number of siblings and family members living in the parental home while the respondent went to school. Afterwards, this variable was coded into a dummy variable taking the value one if the family size is above population average and zero if otherwise. 
Parent-child communication in the family is a self-reported measure on the frequency of exchanges between children and parents about school or studies during secondary education. This variable ranges from "never" (1), "rarely" (2), "sometimes" (3), "regularly" (4) to "often" (5).

Above-average support by teachers. Respondents were asked to think about the teachers in their most important secondary school and to indicate to what extent they agreed on the following statements: "I got along well with most of my teachers," "Most teachers really listened to me" and "I received extra help from my teachers when I needed it." Answer categories varied from "totally disagree" (1) to (5) "totally agree" (Cronbach $\alpha>0.80$ for all groups in both countries). Given that the distribution is skewed towards high agreements with these items we generated a dummy variable out of this index taking the scales' median as the cut point. Thus, above-average support by teachers is a dummy variable coded as one if the perceived support is above average and zero otherwise.

Feeling of being discriminated against in secondary school is a dummy variable coded zero if the answer on the survey question "How often did you personally experience hostility or unfair treatment because of your origin or background while being in secondary school" was "never" and taking the value one for all other answer categories (rarely, occasionally, regularly and frequently).

Ethnic composition of best friends in school and today. ${ }^{9}$ Interviewees were asked to give information on their three best friends (a) during the period of lower secondary education and (b) at the moment of the interview. They were asked to list their three best friends separately for each point in time as well as the ethnicity of each friend. We combined the information on scales as follows: Three dummy variables were generated (one for each best friend - separately for during school and today) indicating whether the friend was of Austrian/Swiss origin or not. Afterwards, all three answer categories were added and divided through the total number of valid answers. We achieved two scales reporting the ethnic composition of the peer groups (a) in school and (b) today, ${ }^{10}$ ranging from 0 (all close friends are co-ethnics) to 1 (all three best friends are of Austrian/ Swiss origin). Both variables are treated as

9 People choose peers who have similar outlooks, and that is why there has been a vigorous debate among researchers about the relative importance of selection versus socialisation in accounting for peer effects on socioeconomic outcomes. Several scholars claim that peer effects found empirically in many studies result from school or job socialisation rather than from peer socialisation itself. Although there is a disagreement about the degree of influence, there is little doubt that selection and actual influence contribute to what are often referred to as "peer effects." Or, as Kao (2001, 439) puts it: "Even the most pro-selection researchers will admit that some peer socialisation must occur."

10 Recall that although we asked for this information at the time of the interview, the composition of peers refers to the three best friends to whom friendships might last already for a longer time period. Establishing strong bonds and close networks of best friends needs time and might have occured already before our respondents achieved their current status. Thus we argue that our peer composition measure today is less affected by selection bias through the respondents' current status. 


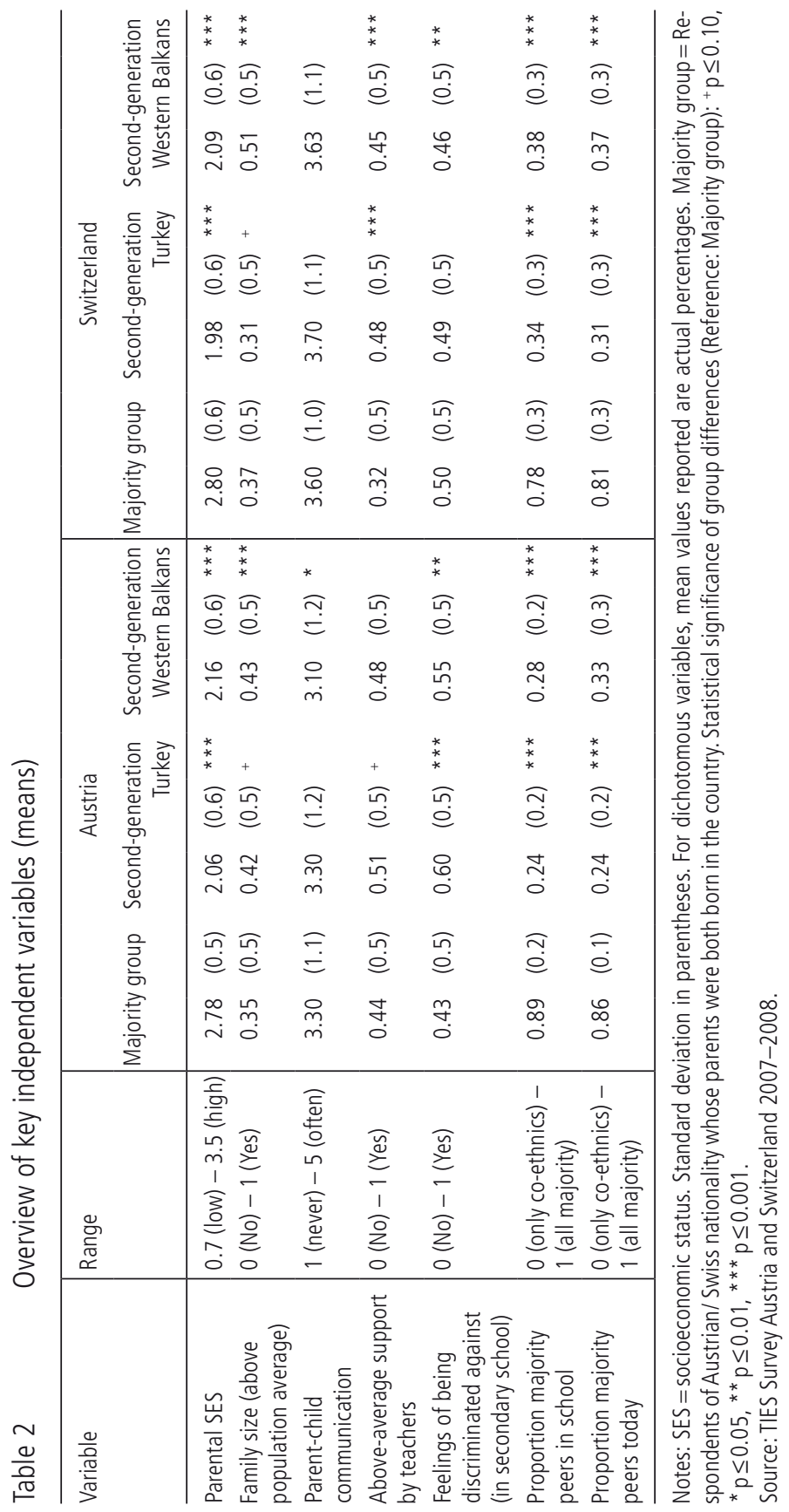


continuous variables in the statistical analysis with an increasing factor score indicating more majority peers among the circle of best friends.

Control variables. We further include gender, age and urban area of residence as control variables.

Descriptive statistics of our main independent variables of interest are displayed in Table $2 .^{11}$

\section{Results: Educational and occupational pathways}

\subsection{Descriptive analysis}

We begin our analysis by providing some descriptive statistics on the four main pathways identified within each country by groups (see Table 3). The first linear trajectory describes the constant successful path. Young adults successfully negotiate through more prestigious tracks in the education system, whether in general or in vocational education, leading to professional or at least routine occupational positions. Around $20 \%$ of all respondents in our data follow this path within each country. A closer look at group differences reveals that respondents of the majority group outperform second-generation young adults on this path. Group differences are about 12 percentage points in favour of the majority group in Switzerland. In Austria, only descendants of Turkish immigrants follow the constant successful path significantly less often (around 14\% compared to 20\% in the majority group) while no differences appear in comparison to the Western-Balkan second-generation (21\%).

The largest proportion of our sample in both countries follows socioeconomic trajectories that lead towards upward mobility. The second-generation of Turkish and Western-Balkan descent is significantly more often climbing upwards $(62 \%$ in each case) compared to majority respondents (41\%) in Switzerland. The difference in upward mobility favours the second-generation. Children of immigrants achieve their mobility most frequently through the apprenticeship which enables them to reach routine and skilled work positions in spite of their elementary lower-secondary school attainment or directly on the labour market. Turning to the findings for Austria, figures indicate that upward mobility does not significantly differ between our study groups. About every second young adult started low in the Austrian education system and constantly moved upwards into routine and skilled work positions.

In both countries, some declining achievers can be identified. They start high in the education systems but either they lose ground, be it within the course of their educational career, or on the labour market after completing education or they ex-

11 The sample used in our analysis contained some missing values in our independent variables of interest (less than $6 \%$ in our sample) and we dealt with this through adopting a multiple imputation (mi) technique using the ICE module in STATA 11 (Royston 2004). We nevertheless replicated all analysis with listwise deletion. These additional analyses yielded substantially similar results. 
Table 3

Distribution of socioeconomic pathways in Austria and Switzerland, by country and group (\%)

\begin{tabular}{|c|c|c|c|c|c|c|}
\hline & \multicolumn{3}{|c|}{ Austria } & \multicolumn{3}{|c|}{ Switzerland } \\
\hline & $\begin{array}{r}\text { Majority } \\
\text { group }\end{array}$ & $\begin{array}{l}\text { Second- } \\
\text { generation } \\
\text { Turkey }\end{array}$ & $\begin{array}{l}\text { Second- } \\
\text { generation } \\
\text { Western } \\
\text { Balkans }\end{array}$ & $\begin{array}{r}\text { Majority } \\
\text { group }\end{array}$ & $\begin{array}{r}\text { Second- } \\
\text { generation } \\
\text { Turkey }\end{array}$ & $\begin{array}{r}\text { Second- } \\
\text { generation } \\
\text { Western } \\
\text { Balkan }\end{array}$ \\
\hline Constant successful path & 20.2 & 13.9 & 20.7 & 28.5 & 16.0 & 16.4 \\
\hline Upward mobility path & 52.6 & 48.6 & 47.9 & 40.5 & 61.8 & 62.2 \\
\hline Downward mobility path & 18.1 & 12.2 & 7.6 & 27.9 & 12.0 & 14.8 \\
\hline Constant unsuccessful path & 9.1 & 25.3 & 23.8 & 3.1 & 10.2 & 6.6 \\
\hline $\mathrm{N}$ & 331 & 352 & 396 & 355 & 374 & 378 \\
\hline
\end{tabular}

Notes: Majority group = Respondents of Austrian / Swiss nationality whose parents were both born in the country. Source: TIES Survey Austria and Switzerland 2007-2008.

perience ups and downs before reaching lower segments on the labour market as a final destination or stepping out of the labour market altogether. Those following the downward mobility path in Switzerland are twice as frequent within the majority group (28\%) as among second-generation youth (12\% second-generation Turkish; $15 \%$ second-generation Western Balkan). In Austria, non-immigrant youngsters are also more often following the downward path $(18 \%)$ as compared to descendants of Turkish (12\%) and Western-Balkan (8\%) immigrants.

Some young adults in both countries move along the bottom line of the socioeconomic spectrum (compare constant unsuccessful path in Table 3). They start low in lower secondary education and (if at all) complete compulsory education with at maximum a vocational degree. Afterwards they are either unemployed or enter the labour market as unskilled workers. The proportion of young adults following this path is particularly large among children of immigrants in Austria. About a quarter of the second-generation is following this pathway compared to $9 \%$ among the majority population. In contrast, followers of the constant unsuccessful path are a marginal group in Switzerland comprising only 7\% of our sample. Turning to the distribution by group we find second-generation from Turkey most frequently being drifters (10\%), followed by second-generation from Western Balkans (7\%) and the majority group $(3 \%)$.

\subsection{Multivariate analyses}

The probability of following one of the four main socioeconomic pathways are now compared between second-generation youth and those of the majority group within each country while considering the explanatory factors outlined above. We ran a 


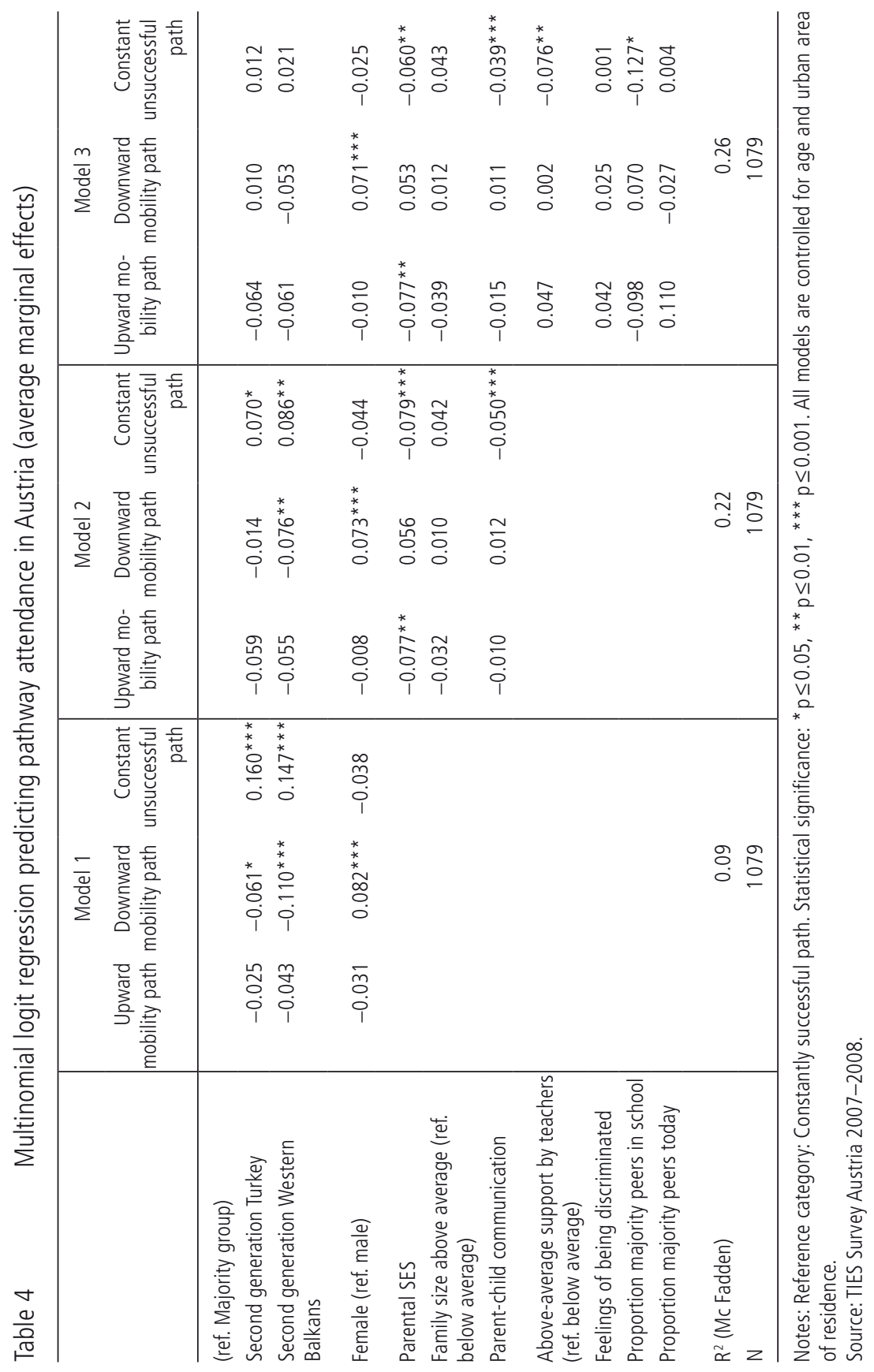


multinomial logistic regression to predict the probability of following the (1) constant unsuccessful path, (2) upward mobility path or the (3) downward mobility path as opposed to following the reference category, (0) constantly successful path. By using a multinomial regression model, we did not make assumptions about the ordering of the different categories. Three models of increasing complexity are estimated. In the first model (Model 1) only group status and our control variables age, gender and place of residence are entered. In a second step, we account for family level factors (parental SES, family size above average and parent-child communication, Model 2). Finally, we introduce above-average support by teachers, peer group composition and feelings of being discriminated against in the last analytical step (Model 3). In order to test for differential effects we estimated interactions among our study groups and core independent variables based on Model 3. We report significant results in the text. Coefficients are average marginal effects (ame) since they are comparable across models and groups (Mood 2010).

The estimates for Austria in Model 1 (Table 4) show - in line with our descriptive findings - that children of immigrants do not differ significantly in the probability of mobility as compared to the majority group. Instead, being of Turkish or Western-Balkan origin is negatively correlated with following a downward mobility path and positively related to being a "drifter" or following an unsuccessful path (Model 1). The Turkish second-generation has a 16 percentage point and the Western-Balkan second generation a 15 percentage point higher probability to follow this constant unsuccessful path as compared to the majority group.

After adjusting for family-related control variables (Model 2), the previously observed higher probability to be on the unsuccessful path for the second-generation halves but remains significant. In addition, the negative effect for second-generation Turks on the downward mobility path disappears after adjusting for the set of measures in Model 2. Looking at the included variables reveals that higher parental SES reduces the probability of following the unsuccessful and the upward mobility path. In other words, children originating from families with higher SES are more likely to avoid the unsuccessful path in favour of the remaining alternatives and have a higher probability to following the successful path right from the beginning. Increasing parent-child communication about schooling matters in the family of origin is negatively associated with following the unsuccessful path. In the final model (Model 3), above-average support by teachers, feelings of being discriminated against and our peer group composition measures are added. Coefficients reveal that greater support by teachers and more majority peers in secondary school significantly increase the probability of avoiding the constant unsuccessful path in favour of the three remaining paths. After holding these variables constant, group differences in the probability of following the constant unsuccessful path disappear. In additional analyses, we tested for differential effects for our study groups and the main independent variables based on Model 3. We could not find any significant 


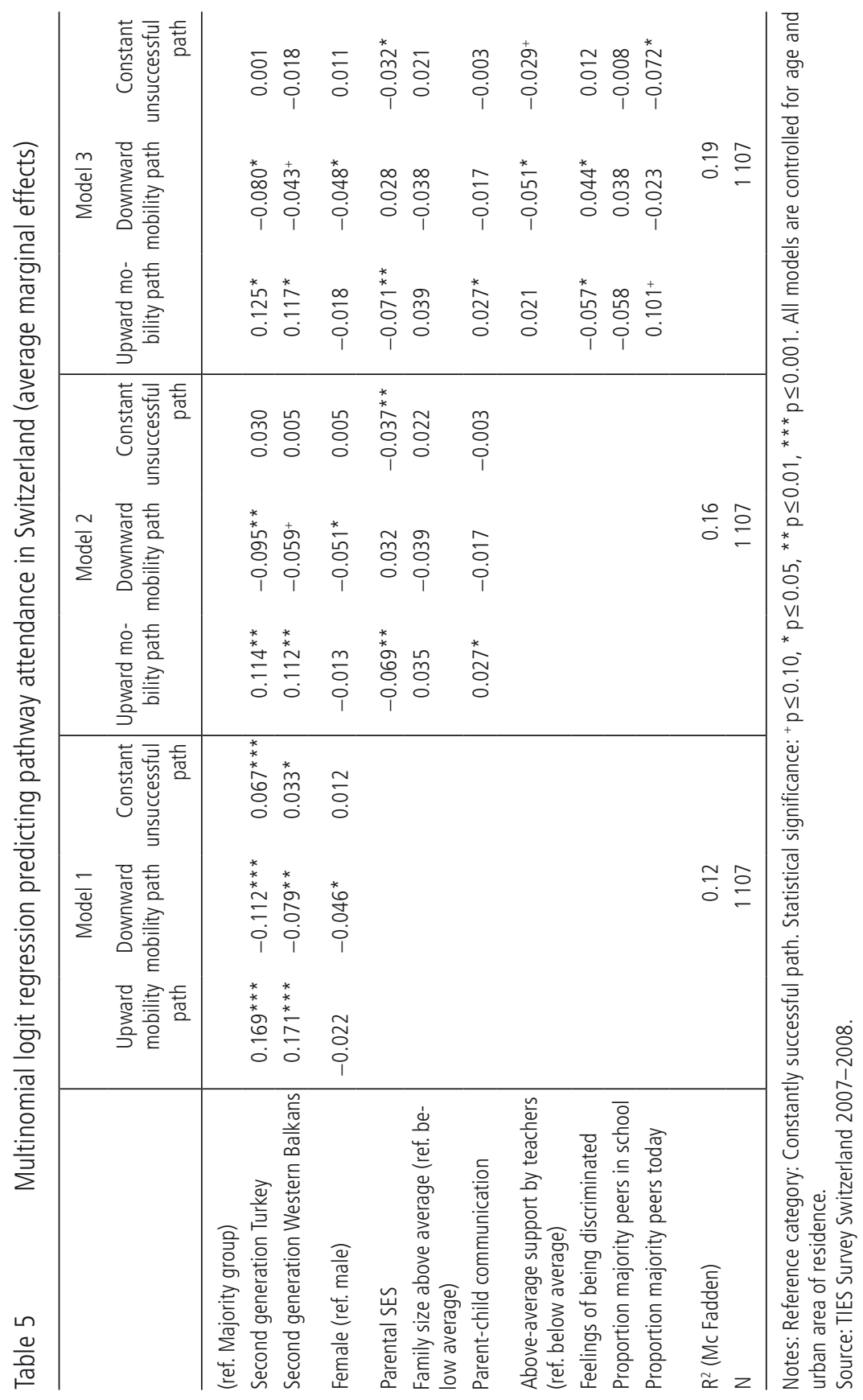


interaction effects indicating that the observed patterns apply equally to all three study groups. For example, an increase in the proportion of majority peers reduces the probability to follow the unsuccessful path for all respondents.

Table 5 provides regression results for the probability of following the various socioeconomic pathways in Switzerland. We apply the same analytical strategy as for Austria. The most important results can be summarized as follows: first, descendants of Turkish and Western-Balkan immigrants are significantly more likely to be on the upward mobility path. They have a 17 percentage point higher probability to climb upwards rather than following any of the remaining pathways compared to the majority group (Model 1). Although this second-generation advantage loses statistical significance when adding the set of independent variables stepwise to our analysis, second-generation groups have still a 12 percentage point higher probability to follow the upward mobility path than the majority group after holding the full set of covariates constant (Model 3). Second, children of the two immigrant groups in Switzerland are more likely to avoid downward mobility in favour of the three remaining paths even after adjusting the results for the full set of covariates. Third, we do not observe any significant group differences at conventional levels for following the constant unsuccessful pathway in Switzerland.

Looking at the effects of our set of independent variables, findings show that higher parental SES is negatively interrelated with upward mobility and the constant unsuccessful path. Note that this finding has also been observed for Austria with almost the same magnitude. Next, parent-child communication is found to be positively related with upward mobility, while feelings of being discriminated against are negatively related to following this path. The probability of making a strong start in the education system but losing grounds afterwards (downward mobility path) is significantly affected by higher perceptions of discrimination, while receiving above-average support by teachers can significantly hamper downward mobility. The negative effect of above-average support by teachers is also found for those following the constant unsuccessful path - albeit at a lower significance level. Having a higher share of majority peers in the present circle of friends increases the probability to be upwardly mobile by 10 percentage points, while reducing the probability to follow the constant unsuccessful path by 7 percentage points.

\subsection{A closer look at upward mobility}

We look into the upward mobility path in more detail below for two reasons: previous studies predominantly focused on the causes of failure and downward mobility rather than on the trajectories of success. Moreover, they constitute the most numerous group in our data (55\% in Switzerland; 50\% in Austria). As described above, the family of those respondents in upward mobility trajectories consists of three main avenues allowing for upward mobility: within education (ED), on the labour market $(\mathrm{LM})$ or through both channels $(\mathrm{ED}+\mathrm{LM})$. Figure 2 displays those 
Figure 2 Upward mobility through different paths, by country and group (\%)

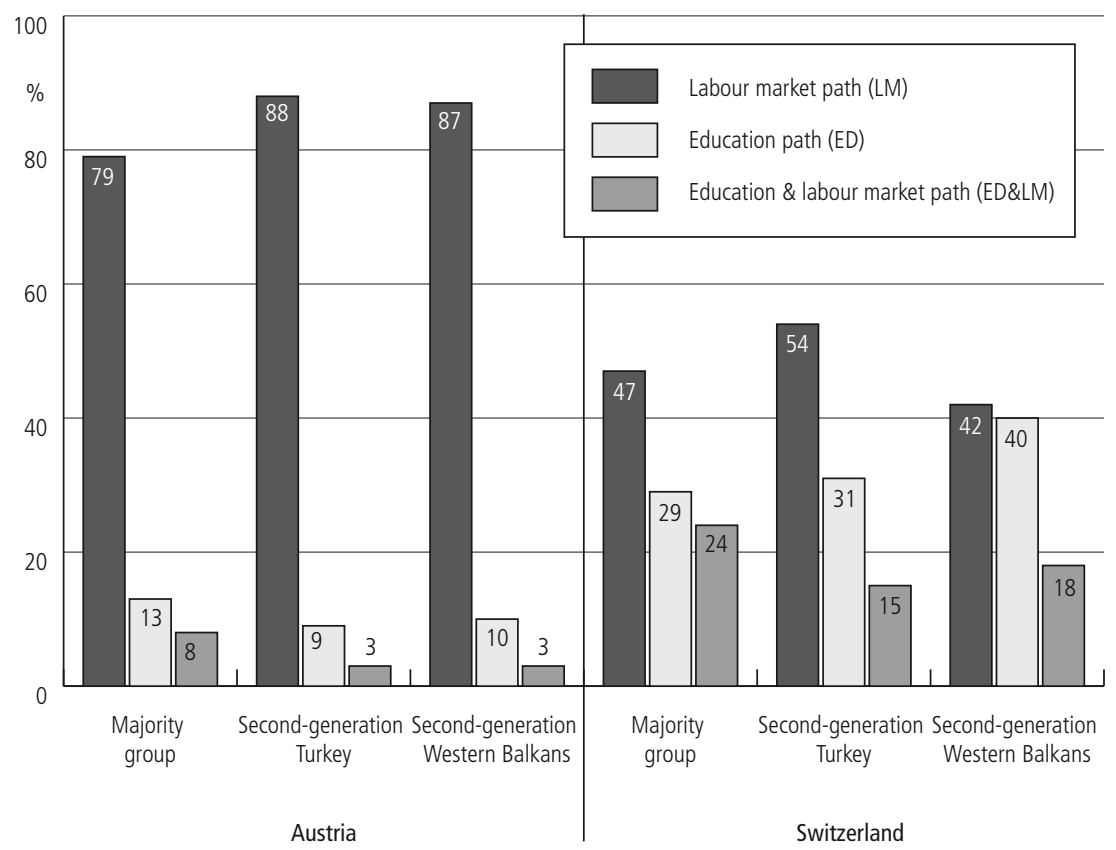

Source: TIES Survey Austria and Switzerland 2007-2008.

respondents following the upward mobility path separately by the three potential upward trajectories.

In Austria, $80 \%(\mathrm{~N}=137)$ of the majority group and around $88 \%$ among the descendants of Turkish and Western-Balkan immigrants $(\mathrm{N}=150$ and 165, respectively) move up through the labour market while only around $10 \%$ of the Turkish and Western-Balkan second generation ( $\mathrm{N}=16$ and 19, respectively) achieves upward mobility within the Austrian education system. Consistent with previous findings (Schnell 2014), our results show that because of the limited permeability between tracks in upper secondary education within the Austrian education system, chances to move upward after having been streamed into the vocational track (Hauptschule) remains low. The stakes seem to be high against obtaining the marks required for entering the academic tracks in upper-secondary education, in particular for children of immigrants. Consequently, upward mobility can only be achieved through the labour market avenue once they have left the school system. 
Although upward mobility through the labour market is also the most common type in Switzerland, the proportion is significantly lower as compared to Austria: around $50 \%$ of all "climbers" are upward mobile through the Swiss labour market while roughly one third moved upwards through the education system. More precisely, 31\% among the Turkish second generation $(\mathrm{N}=71)$ and $40 \%(\mathrm{~N}=94)$ young adults of Western-Balkan origin rise within the Swiss education system. Nine out of ten of these climbers move upwards between lower and secondary education while the remaining 10\% make it into post-secondary education after finishing secondary education. This finding is in line with previous studies indicating that the highly institutionalized trajectories in Switzerland, in particular towards upper secondary education, are substantially reducing the chance to end up in low paid, unskilled work or unemployment (Gaupp et al. 2012). Being upward mobile in education and later on the labour market is least common among young adults in both countries.

This study focused on educational and occupational trajectories of descendants of immigrants from Turkey and Western-Balkans in Austria and Switzerland. Comparing these two countries is interesting because they share a number of generic institutional arrangements in the education system and have comparable migration regimes. At the same time, both countries diverge in less pronounced and often neglected institutional features which provide varying opportunities and different rates of upward mobility between the two countries. How the second-generation experiences socioeconomic mobility in Austria as compared to Switzerland was at the heart of our analysis. We addressed the question of cross-national differences in the educational and occupational mobility of children of immigrants by studying socioeconomic pathways from the beginning of school tracking until the current position in the labour market.

To begin with, our results indicate a major similarity between both compared countries. The likelihood of consistent progress through prestigious tracks in the Austrian or Swiss education system leading to professional or at least routine occupational positions is significantly lower for children of Turkish or Western-Balkan immigrants as compared to the respective majority groups. This disadvantage experienced by the second-generation can largely be explained by the intergenerational transmission of parental resources, such as parental socioeconomic status. Thus, our findings mirror previous results in social stratification research on the degree of intergenerational educational mobility in Switzerland and Austria which found strong correlations between social origin and the highest and prestigious educational and occupational attainment due to intense differentiation of students into different ability tracks early in the education system (Buchmann and Dalton 2002; Pfeffer 2008; Laganà 
et al. 2014). Rigid and early selection of students appears to magnify inequalities in educational attainment because it gives children of immigrants insufficient time to leave their disadvantaged starting positions (van de Werfhorst et al. 2014, 262).

Our findings reveal further that although children of Turkish and WesternBalkan immigrants do not enter the prestigious constant successful path that leads directly to high level occupations in the same numbers as the majority group in both countries, they are persistent and constantly improving their achievements through alternative routes as they move through education and work. However, differences between the two compared countries appeared in the number of "climbers" among children of Turkish and Western-Balkan immigrants indicating that the chances to be upward mobile are higher for young adults of immigrant origin in Switzerland than in Austria. Although direct causal effects are hard to prove with the available data, our findings do clearly point in a certain direction: young adults in Austria follow more often the constant unsuccessful path as compared to Switzerland because of a lower degree of permeability within the Austrian education system. These young adults start low in education and (if at all) complete compulsory education at maximum with a vocational degree. Afterwards they are either unemployed or enter the labour market as unskilled workers. This pattern applies in particular to descendants of Turkish and Western-Balkan immigrants in Austria. Because there are few opportunities to move upwards towards upper-secondary tracks (degree of permeability) after this selection moment in the Austrian education system - as also indicated by the low rates of upward mobility through education (compare Figure 2) - opportunities to leave the unsuccessful path and enter the route of upward mobility remain low. Our multivariate regression analyses indicate further that achieving such a turning point, i. e. leaving the unsuccessful path in the Austrian education system, depends significantly on resources in the family home (parental SES; frequent parent-child communication) as well as on additional and above average support by teachers. Because the great majority of these young adults lack resources relevant for socioeconomic success, they have limited chances to leave the unsuccessful path. By contrast, the highly institutionalized trajectories in Switzerland, in particular towards upper secondary education, are substantially increasing the chance to leave the unsuccessful path and move up within the education system. The number of upward climbers via this route may even increase in the near future because efforts have been made to advance vocational and educational training (VET) in Switzerland. Academically weaker learners should now be integrated into the VET system, "making it easier for people without post-compulsory qualifications to obtain a qualification by validating the skills they have acquired non-formally or informally, and also creating attractive options for highly talented students" (SKBF 2014, 121-122). This development might improve the chances for upward mobility of second-generation immigrants who start low and try to engage in upward trajectories afterwards. 
Two findings should be subject to further research. First, second-generation youth of both origin groups in Switzerland are significantly more often upwardly mobile than the majority group. The observed second-generation advantage persists even after taking all independent variables in our multivariate analysis into account. One possible reason might be their higher levels of educational and occupational aspirations. Several studies point to the importance of academic aspirations as achievement motivations predicting educational and occupational attainment for children of immigrants "against all odds" and preventing downward mobility as compared to non-immigrant youth (Brinbaum and Kieffer 2005; Ravecca 2009; Becker 2010; Relikowski et al. 2012; Santelli 2013). Our data do not have information on aspirations, however, a recent study indicates significant correlations between educational aspirations and successful educational trajectories among immigrant youth in the Swiss context (Stamm 2013). Future studies should examine the role of aspirations as a potential explanation of this second-generation advantage and their impact on upward mobility.

Second, and partially due to data limitations, we have treated "climbers" as a rather broad study group. However, there might be variation within this group which should be subject to future research. Some young adults who depart from lower tracks in the education systems entered mainstream positions in the labour market, such as skilled or routine positions, while some climbers experienced rather exceptional degrees of upward mobility by achieving professional positions despite their low starting point. Thus, forthcoming studies should investigate more closely the range of upward mobility among climbers of immigrant descendants in the Swiss and Austrian labour market. More research is also needed on the concrete mechanisms and factors that lead to upward mobility for children of immigrants in the labour market - an analysis that was beyond the scope of our paper due to small sample sizes.

In addition, future studies should longitudinally examine the educational and occupational trajectories on a large and representative sample beyond city samples and test whether our findings hold for both countries as a whole. Such a design would also allow the inclusion of respondents who are still in school and without labour market experience - a subsample that has not been studied within this contribution but which might even increase the proportion of young adults in successful trajectories.

\section{$7 \quad$ References}

Alba, Richard, Jennifer Sloan, and Jessica Sperling. 2011. The Integration Imperative: The Children of Low-

Status Immigrants in the Schools of Wealthy Societies. Annual Review of Sociology 37: 395-415.

Bacher, Johann. 2010. Bildungschancen von Kindern mit Migrationshintergrund. WISO 33(1): 30-48. 
Becker, Birgit. 2010. Bildungsaspirationen von Migranten: Determinanten und Umsetzung in Bildungsergebnisse. Mannheimer Zentrum für Europäische Sozialforschung Arbeitspapiere 137, http://www. mzes.uni-mannheim.de/publications/wp/wp-137.pdf (10.09.2015).

Bertschy, Kathrin, Edi Böni, and Thomas Meyer. 2007. Les jeunes en transition de la formation au monde du travail. Survol de résultats de la recherche longitudinale TREE, http://edudoc.ch/record/33360/ files/TREE_Ergebnis-Updatewie-Resultat9_2007_frz.pdf (12.01.2015).

Brinbaum, Yaël, and Annick Kieffer. 2005. D’une génération à l'autre, les aspirations éducatives des familles immigrées: Ambition et perséverance. Éducation et formations 72(9): 53-75.

Buchmann, Claudia, and Ben Dalton. 2002. Interpersonal Influences and Educational Aspirations in 12 countries: The Importance of Institutional Context. Sociology of Education 75(2): 99-122.

Campbell, Bruce A. 1980. A Theoretical Approach to Peer Influence in Adolescent Socialization. American Journal of Political Science 24(2): 324-344.

Crul, Maurice, and Jens Schneider. 2010. Comparative Context Integration Theory. Participation and in Belonging in Europe's Large Cities. Ethnic and Racial Studies 34(4): 1249-1268.

Crul, Maurice, Jens Schneider, and Frans Lelie. 2012. The European Second Generation Compared: Does the Integration Context Matter? Amsterdam: Amsterdam University Press.

Crul, Maurice, Philipp Schnell, Barbara Herzog-Punzenberger, Maren Wilmes, Marieke Slootman, and Rosa Aparicio-Gomez. 2012. School Careers of Second-Generation Youth in Europe. Which Education Systems Provide the Best Chances for Success? Pp. 101-164 in The European Second Generation compared: Does the Integration Context Matter?, edited by Maurice Crul, Jens Schneider, and Frans Lelie. Amsterdam: Amsterdam University Press.

Duncan, Greg J., Johanne Boisjoly, and Kathleen. M. Harris. 2001. Sibling, Peer, Neighbor, and Schoolmate Correlations as Indicators of the Importance of Context for Adolescent Development. Demography 38(3): 437-447.

Erikson, Robert, John H. Goldthorpe, and Lucianne Portocarero. 1979. Intergenerational Class Mobility in Three Western European Societies: England, France, and Sweden. British Journal of Sociology 30: 415-430.

Eurostat. 2013a. Elèves dans la filière professionnelle de l'enseignement secondaire supérieur. Data. Eurostat, http://epp.eurostat.ec.europa.eu/tgm/table.do?tab=table\&init=1\&plugin=1\&languag $\mathrm{e}=$ fr\&pcode $=$ tps00055 (27.11.2013)

Eurostat. 2013b. Expenditure on education as \% of GDP or public expenditure. Data. Eurostat, http:// appsso.eurostat.ec.europa.eu/nui/show.do (27.11.2013).

Fibbi, Rosita, Mathias Lerch, and Philippe Wanner. 2006. Unemployment and Discrimination against Youth of Immigrant Origin in Switzerland: When the Name Makes the Difference. Journal of International Migration and Integration 7(3): 351-366.

Fibbi, Rosita, Ceren Topgül, Dusan Ugrina, and Philippe Wanner. 2015. The New Second Generation: Youth of Turkish and Former Yugoslav Descent in Zurich and Basel. Amsterdam: Amsterdam University Press.

Gaupp, Nora, Boris Geier, and Sandra Hupka-Brunner. 2012. Chancen bildungsbenachteiligter junger Erwachsener in der Schweiz und in Deutschland: Die (Nicht)Bewältigung der zweiten Schwelle. Zeitschrift für Soziologie der Erziehung und Sozialisation 32(3): 299-318.

Gibson, Margret A., Patricia. Gándara, and Jill Peterson Koyama. 2004. The Role of Peers in the Schooling of U.S. Mexican Youth. Pp. 1-17 in School Connections: U.S. Mexican Youth, Peers, and School Achievement, edited by Magret A. Gibson, Patricia Gándara, and Jill Peterson Koyama. New York: Teachers College Press.

Glick, Jennifer E., and Michael J. White. 2003. Academic Trajectories of Immigrant Youths: Analysis Within and Across Cohorts. Demography 40(4): 759-783.

Gomez-Salvador, Ramon, and Nadine Leiner-Killinger. 2008. An Analysis of Youth Unemployment in the Euro Area. Occasional Paper Series European Central Bank 89. 
Gomolla, Mechtild, and Frank-Olaf Radtke. 2000. Mechanismen institutionalisierter Diskriminierung in der Schule. Pp. 321-341 in Migration, gesellschaftliche Differenzierung und Bildung. Resultate des Forschungsschwerpunktprogramms FABER, edited by Ingrid Gogolin and Bernhard Nauck. Wiesbanden: Springer VS.

Groenewold, George, and Laurence Lessard-Phillips. 2012. Research Methodology. Pp. 39-58 in The European Second Generation Compared: Does the Integration Context Matter? edited by Maurice Crul, Jens Schneider, and Frans Lelie. Amsterdam: Amsterdam University Press.

Groh-Samberg, Olaf, Ariane Jossin, Carsten Keller, and Ingrid Tucci. 2012. Biographische Drifts und Zweite Chance. Bildungs- und Berufsverläufe von Migrantennachkommen in Deutschland und Frankreich. Pp. 186-210 in Soziologische Bildungsforschung, Kölner Zeitschrift für Soziologie und Sozial Psychologie, Sonderheft 52, edited by Heike Solga and Rolf Becker. Wiesbaden: Springer VS.

Hao, Lingxin, and Suet-Ling Pong. 2008. The Role of School in the Upward Mobility of Disadvantaged Immigrants' Children. The ANNALS of the American Academy of Political and Social Science 620(1): 62-89.

Heath, Anthony F., and Yaël Brinbaum (Eds.). 2014. Unequal Attainments. Ethnic Educational Inequalities in Ten Western Countries. Oxford: Oxford University Press.

Herzog-Punzenberger, Barbara. 2003. Ethnic Segmentation in School and Labour Market - 40 Year Legacy of Austrian Guest Worker Policy. International Migration Review 37(4): 1120-1144.

Hupka-Brunner, Sandra, Thomas Meyer, Barbara E. Stalder, and Anita C. Keller. 2012. Übergänge im Spannungsfeld zwischen sozialer Herkunft, Leistung und Strukturen des Bildungssystems. Pp. 203-220 in Bildung-Arbeit-Erwachsenwerden. Ein interdisziplinärer Blick auf die Transition im Jugend und jungen Erwachsenenalter, edited by Manfred M. Bergman, Sandra Hupka-Brunner, Thomas Meyer, and Robin Samuel. Wiesbaden: Springer VS Verlag.

Juhasz, Anne, and Eva Mey. 2003. Die zweite Generation: Etablierte oder Außenseiter? Biographien von Jugendlichen ausländischer Herkunft. Wiesbaden: Westdeutscher Verlag.

Kanas, Agnieszka, Frank Van Tubergen, and Tanja Van der Lippe. 2011. The Role of Social Contacts in the Employment Status of Immigrants A Panel Study of Immigrants in Germany. International Sociology 26(1): 95-122.

Kao, Grace. 2001. Race and Ethnic Differences in Peer Influences on Educational Achievement. Pp. 437-460 in The Problem of the Century: Racial Stratification in the U.S. at the Millenium, edited by Douglas S. Massey and Elijah Anderson. New York: Russell Sage.

Kao, Grace, and Lindsay T. Rutherford. 2007. Does Social Capital Still Matter? Immigrant Minority Disadvantages in School-specific Social Capital and its Effort on Academic Achievement. Sociological Perspectives 50(1): 27-52.

Kasinitz, Philip, John H. Mollenkopf, Mary C. Waters, and Jennifer Holdaway. 2008. Inheriting the City: The Children of Immigrants Come of Age. New York: Russell Sage Foundation and Harvard University Press.

Kolenikov, Stanislav, and Gustavo Angeles. 2009. Socioeconomic Status Measurement with Discrete Proxy Variables: Is Principal Component Analysis a Reliable Answer? Review of Income and Wealth 55(1): 128-165.

Kronig, Winfried. 2007. Die systematische Zufälligkeit des Bildungserfolgs. Bern: Haupt Verlag.

Laganà, Francesco, Julien Chevillard, and Jacques-Antoine Gauthier. 2014. Socio-economic Background and Early Post-compulsory Education Pathways: A Comparison between Natives and SecondGeneration Immigrants in Switzerland. European Sociological Review 30(1): 18-34.

Loury, Glenn. 2002. The Anatomy of Racial Equality. Cambridge, MA: Harvard University Press.

Meyer, Thomas. 2003. Parcours vers les formations postobligatoires. Les deux premières années après l'école obligatoire. Résultats intermédiaires de l'étude longitudinale TREE. Neuchâtel: Swiss Federal Statistical Office. 
Mood, Carina. 2010. Logistic Regression: Why We Cannot Do What We Think We Can Do, and What We Can Do About It. European Sociological Review 26(1): 67-82.

Nations Unies. 2008. Indicateurs des objectifs du millénaire pour le développement. http://mdgs.un.org/ unsd/mdg/Host.aspx? Content=indicators/officiallist.htm (30.06.2015).

OECD. 2012. Employment Outlook 2012. Paris: OECD Publishing.

Pfeffer, Fabian T. 2008. Persistent Inequality in Educational Attainment and Its Institutional Context. European Sociological Review 24(5): 543-565.

Portes, Alejandro, and Ruben G. Rumbaut. 2001. Legacies. The Story of the Immigrant Second Generation. New York: Russell Sage Foundation.

Ravecca, Andrea. 2009. Studiare nonostante. Capitale sociale e successo scolastico degli studenti di origine immigrata nella scuola superiore. Milano: Franco Angeli.

Relikowski, Ilona, Erbil Yilmaz, and Peter Blossfeld. 2012. Wie lassen sich die hohen Bildungsaspirationen von Migranten erklären? Eine Mixed-Methods-Studie zur Rolle von strukturellen Aufstiegschancen und individueller Bildungserfahrung. Pp. 111-136 in Soziologische Bildungsforschung, Kölner Zeitschrift für Soziologie und Sozial Psychologie, Sonderheft 52, edited by Heike Solga and Rolf Becker. Wiesbaden: Springer VS Verlag.

Romans, Fabrice, and Vivian Preclin. 2008. European Union Labour Force Survey - Annual results 2007. Eurostat Data en Focus 27.

Rosenbaum, James E., Stefanie DeLuca, Shazia R Miller, and Kevin Roy. 1999. Pathways into Work: Shortand Long-Term Effects of Personal and Institutional Ties. Sociology of Education 72(3): 179-196.

Royston, Patrick. 2004. Multiple Imputation of Missing Values. Stata Journal 4: 227-241.

Santelli, Emannuelle. 2013. Upward Social Mobility among Franco-Algerians. The Role of Family Transmission. Swiss Journal of Sociology 39(3): 551-573.

Schnell, Philipp. 2014. Educational Mobility of Second-Generation Turks. Cross-National Perspectives. IMISCOE Research. Amsterdam: Amsterdam University Press.

Schnell, Philipp, and Rosita Fibbi. 2015. Getting Ahead: Educational and Occupational Trajectories of the "New" Second Generation in Switzerland. Journal of International Migration and Integration, http://dx.doi.org/10.1007/s12134-015-0452-y (30.06.2015).

Sievers, Wiebke, Ilker Atac, and Philipp Schnell. 2014. Turkish Migrants and Their Descendants in Austria: Patterns of Exclusion and Individual and Political Responses. Migration Letters 11(3): 263-274.

Simon, Patrick. 2012. Collecting Ethnic Statistics in Europe: A Review. Ethnic and Racial Studies 35(8): 1366-1391.

SKBF. 2014. Swiss Education Report. Aarau: SKBF-CSRE.

Skrobanek, Jan. 2014. Ethnisierung von Ungleichheit. Disparitäten, Benachteiligungswahrnehmung und Selbstethnisierungsprozesse im Übergang Schule - Ausbildung. Weinheim, Basel: Beltz Juventa.

Stamm, Magrit. 2013. Typen ausbildungserfolgreicher Migranten. Zeitschrift für Berufs- und Wirtschaftspädagogik 109(2): 216-231.

Stanton-Salazar, Ricardo D. 2001. Manufacturing Hope and Despair: The School and Kin Support Networks of U.S.-Mexican Youth. New York: Teachers College Press.

Turney, Kristin, and Grace Kao. 2009. Barriers to School Involvement: Are Immigrant Parents Disadvantaged? The Journal of Educational Research 102(4): 257-271.

van de Werfhorst, Herman G., Erika van Elsas, and Anthony F. Heath. 2014. Origin and Destination Effects on the Educational Careers of Second-Generation Minorities. Pp. 245-271 in Unequal Attainments. Ethnic Educational Inequalities in Ten Western Countries, edited by Anthony F. Heath and Yaël Brinbaum. Oxford: Oxford University Press. 